\title{
Dissociative anesthetic combination reduces intraocular pressure (IOP) in rabbits
}

\section{Associações anestésicas baseadas em fármacos dissociativos reduzem a pressão intraocular (PIO) em coelhos}

\author{
Ewaldo de Mattos-Junior ${ }^{1 *}$; Olicies da Cunha²; Luis Felipe Moraes Barros 3 ; \\ Antonio Humberto Hamad Minervino ${ }^{4}$; Lilian Toshiko Nishimura ${ }^{5}$; \\ Luis Gustavo Gosuen Gonçalves Dias ${ }^{6}$; Silvia Renata Gaido Cortopassi ${ }^{7}$
}

\begin{abstract}
The aim of this study was evaluate the effects of three anesthetic combinations, ketamine-midazolam, ketamine-xylazine and tiletamine-zolazepam, on IOP in rabbits. In a experimental, blind, randomized, crossover study, six rabbits were anesthetized with each of 3 treatments in random order. Groups KM (ketamine, $30 \mathrm{mg} / \mathrm{kg}$ + midazolam, $1 \mathrm{mg} / \mathrm{kg}$ ); KX (ketamine, $30 \mathrm{mg} / \mathrm{kg}$ + xylazine, $3 \mathrm{mg} / \mathrm{kg}$ ); and TZ (tiletamine + zolazepam, $20 \mathrm{mg} / \mathrm{kg}$ ). The drugs were mixed in the same syringe injected intramuscularly (IM) into the quadriceps muscle. IOP was measured before drug administration (baseline) and at 5-minute intervals for 30 minutes. The data were analyzed by a 2-way repeated measures ANOVA followed by Bonferroni test. All groups had significant decreases in IOP compared to baseline $(p<0.001)$. There was no difference between groups at any of the time points assessed $(p>0.05)$. Administration of either ketamine-midazolam, ketamine-xylazine, or tiletamine-zolazepam similarly decrease IOP in rabbits within 30 minutes of injection.
\end{abstract}

Key words: Ketamine, midazolam, Oryctolagus cuniculus, tiletamine, xylazine, zolazepam

\section{Resumo}

O objetivo do presente estudo foi o de avaliar os efeitos das associações anestésicas cetaminamidazolam, cetamina-xilazina e tiletamina-zolazepam sobre a PIO em coelhos. Em estudo do tipo prospectivo, experimental, "cego", "cruzado" e randomizado, foram utilizados seis coelhos distruibuídos aleatoriamente em três tratamentos, designados como grupos CM (cetamina $30 \mathrm{mg} / \mathrm{kg}+$ midazolam, $1 \mathrm{mg} / \mathrm{kg}$ ), CX (cetamina, $30 \mathrm{mg} / \mathrm{kg}$ + xilazina, $3 \mathrm{mg} / \mathrm{kg}$ ) e TZ (tiletamina + zolazepam, $20 \mathrm{mg} / \mathrm{kg}$ ), associados na mesma seringa e aplicados por via intramuscular no músculo quadriceps femoral. A PIO foi mensurada previamente a administração dos fármacos (basal) e com 5 minutos de intervalo por um

\footnotetext{
${ }^{1}$ Prof. de Anestesiologia Veterinária, Universidade de Franca, UNIFRAN, Franca, SP, Brasil. E-mail ewaldomattos@hotmail.com

2 Prof. de Patologia Cirúrgica, Universidade Federal do Paraná, UFPR, Campus Palotina, Palotina, PR, Brasil. E-mail: olicies@ufpr.br

${ }^{3}$ Pesquisador do Laboratório de Oftalmologia Comparada, Faculdade de Medicina Veterinária e Zootecnia, Universidade de São Paulo, USP, São Paulo, SP, Brasil. E-mail: luizfelipembarros@hotmail.com

${ }^{4}$ Prof. de Fisiologia, Universidade Federal do Oeste do Pará, UFOPA, Santarém, PA, Brasil. E-mail: hhamad@bol.com.br

${ }^{5}$ Discente do curso de Mestrado em Medicina Veterinária de Pequenos Animais, UNIFRAN, Franca, SP, Brasil. E-mail:liliannishimura@ hotmail.com

${ }^{6}$ Prof. de Patologia Cirúrgica, Universidade Estadual Paulista, UNESP, Campus de Jaboticabal, Jaboticabal, SP, Brasil. E-mail:gustavogosuen@gmail.com

${ }^{7}$ Prof ${ }^{a}$ de Anestesiologia Veterinária, Faculdade de Medicina Veterinária e Zootecnia, USP, São Paulo, SP, Brasil. E-mail: silcorto@ usp.br

* Author for correspondence
} 
período de 30 minutos. Os dados foram comparados pela análise de variância (ANOVA) de amostras repetidas seguidas pelo teste de Bonferroni. Em todos os grupos foi verificado redução significativa da PIO comparativamente ao valor basal $(\mathrm{p}<0,001)$. Não foi observado diferença entre os grupos em nenhum momento $(\mathrm{p}>0,05)$. A administração das associações cetamina-midazolam, cetamina-xilazina e tiletamina-zolazepam reduzem a PIO de maneira similar em coelhos em até 30 minutos da aplicação.

Palavras-chave: Cetamina, midazolam, Oryctolagus cuniculus, tiletamina, xilazina, zolazepam

\section{Introduction}

Rabbits (Oryctolagus cuniculus) are frequently used as experimental models for various ophthalmic studies, which often include the measurement of intraocular pressure (IOP). Anesthetic agents used to facilitate ophthalmic examination procedures may induce significant IOP changes.

Ketamine administered alone or in combination with diazepam, xylazine or acepromazine, is reported to increase IOP in dogs and rabbits (HOFMEISTER et al. 2006; GHAFFARI; MOGHADDASSI, 2010). In contrast, no increase in IOP was measured after administration of ketamine following diazepam and meperidine (CUNNINGHAM; BARRY, 1986); similarly, xylazine was found to attenuate the effects of ketamine on IOP in horses (TRIM; COLBERN; MARTIN, 1985).

Dissociative anesthetic drug combinations are widely used and recommended for chemical restraint in rabbits (DUPRAS et al., 2001; FLACKNELL; RICHARDSON; POPOVIC, 2007), but the literature on its effects on IOP in this species is scarce. Thus, the aim of this study was to compare the effects of ketamine-midazolam, ketaminexylazine, or tiletamine-zolazepam on IOP in rabbits. We hypothesized that these drug combinations will increase IOP in rabbits.

\section{Material and methods}

The study was approved by the Institutional Animal Care and Use Committee (protocol n. $1763 / 2009$ ), and it followed the ethical principles and practices of animal experimentation.

\section{Animals}

Six male New Zealand rabbits weighing $3.5 \pm 0.3 \mathrm{~kg}$ were used in this study. The rabbits were acclimated to the study environment for 30 days. The room where the study was realized was maintained at controlled temperature $\left(22-24^{\circ} \mathrm{C}\right)$. The rabbits were healthy, as assessed by clinical examination. Prior to the study, biomicroscopy and indirect ophthalmoscopy were performed to confirm eye integrity of the animals.

\section{Experimental design}

The rabbits received each anesthetic drug treatment in random order in a crossover study, with a minimum interval of 7 days between treatments. The anesthetic combinations were KM that was ketamine $(30 \mathrm{mg} / \mathrm{kg}, 100 \mathrm{mg} / \mathrm{mL}$ - Vetaset, Pfizer, Campinas, SP, Brazil) and midazolam (1 mg/kg, 5 $\mathrm{mg} / \mathrm{mL}$ - Dormire, Cristália, Itapira, Brazil), KX that was ketamine (30 mg/kg and xylazine $3 \mathrm{mg} / \mathrm{kg}, 20$ mg/mL - Rompum, Bayer, São Paulo, SP, Brazil), and $\mathrm{TZ}$ that was tiletamine + zolazepam $(20 \mathrm{mg} /$ $\mathrm{kg}, 50 \mathrm{mg} / \mathrm{mL}$ - Zoletil, Jurubatuba, SP, Brazil). The drugs were mixed in the same syringe and injected intramuscularly (IM) into the quadriceps muscle.

IOP was measured before drug administration (baseline) and at 5, 10, 15, 20, 25, and 30 minutes after drug administration.

\section{Evaluation of intraocular pressure}

IOP was measured by applanation tonometry with the Tono-Pen Vet (Reichert Inc. Depew, NY, USA) tonometer after topical instillation of one 
drop of proparacaine $0.5 \%$ anesthetic solution. One person with experience with the equipment performed IOP measurements. The equipment was calibrated prior to the start of the study and according to the manufacturer's instructions. Values were recorded only when the error reported by the equipment was less than $5 \%$.

The rabbits were supported in sternal recumbency with their heads elevated to the level of the thoracic vertebrae. Oxygen was administered via facemask. Heart rate, respiration rate, and hemoglobin oxygen saturation data were recorded throughout the procedure.

\section{Statistical method}

Statistical analysis was performed using the GraphPad PRISM software (version 5.0, GraphPad
Software, Inc, CA, USA). Shapiro-Wilk test was performed and the data were subsequently compared with two-way repeated measures analysis of variance (ANOVA) followed by Bonferroni test. $p<0.05$ was considered to be statistically significant. Data are expressed as mean \pm standard deviation (SD).

\section{Results}

There was a statistically significant decrease in IOP in all groups compared to baseline $(p<0.001)$ (Figure 1). No statistical difference in IOP was observed between eyes and treatment groups ( $p$ $>0.05)$. A statistical difference was not observed in the heart rate, respiratory rate and oxygen saturation at baseline or intra-anesthetic time points $(p>0.05)$

Figure 1. Mean $\pm \mathrm{SD}$ of IOP in rabbits submitted to anesthetic combination ketamine-midazolam (KM), ketaminexylazine (KX) and tiletamine-zolazepam (TZ) in different times of evaluation.

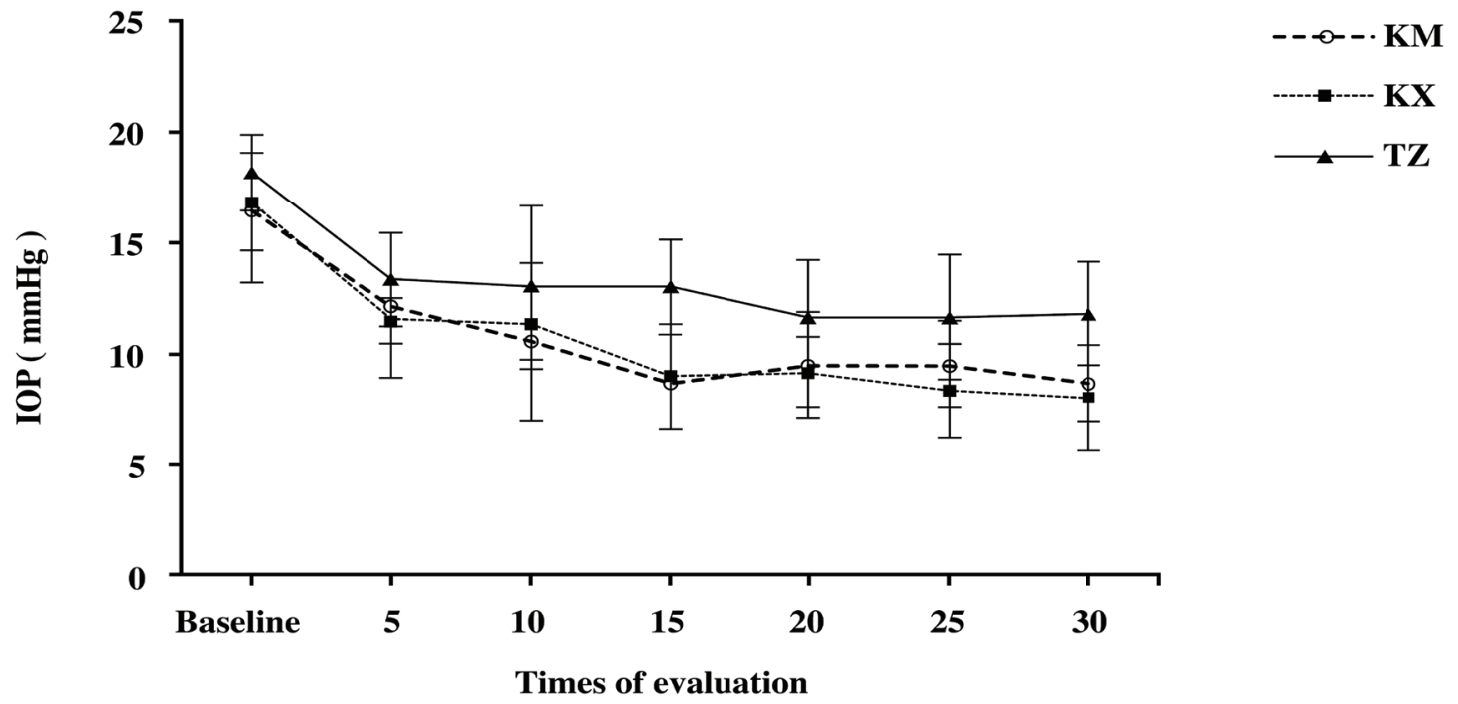

Source: Elaboration of the authors.

\section{Discussion}

The doses of the combinations used in the present study have been described by Dupras et al. (2001), and produce similar anesthetic levels. The mean IOP values at baseline were similar to those described by other authors for this species, and were within the normal reference range (GHAFFARI; MOGHADDASSI, 2010). When all treatment 
groups were considered, the mean IOP value postinjection was $37 \%$ lower than the baseline IOP, with one treatment group (KX) having a maximum decrease of $52 \%$.

Ketamine injected changes a pressure change via contraction of the extraocular muscles (BRUNSON, 1980), but in humans, the effects of this drug on IOP are controversial. Administration of doses up to $8 \mathrm{mg} / \mathrm{kg}$ of ketamine alone in children does not induce changes in IOP (AUSINSCH et al., 1976) but in adult, doses lower than $5 \mathrm{mg} / \mathrm{kg}$ increases IOP (CUNNINGHAM; BARRY, 1986).

Usually in clinical practice, ketamine is not used alone and may be combined with benzodiazepines or $\alpha_{2}$-agonists. The effects of dissociative anesthetic combinations on IOP have been studied in dogs, horses, and rabbits (HOFMEISTER et al., 2006; TRIM; COLBERN; MARTIN, 1985; GHAFFARI; MOGHADDASSI, 2010).

In dogs and rabbits, ketamine-diazepam, given intravenously(IV) and IMrespectively, increases IOP within 20 minutes after injection (HOFMEISTER et al., 2006; GHAFFARI; MOGHADDASSI, 2010). However, Ghaffari et al. (2010) found that in dogs the combination of ketamine with midazolam in dogs did not change in IOP after 20 minutes of administration. In general, benzodiazepines reduce IOP, and a possible explanation for this effect is the relaxation of the extraocular muscle and an increased outflow of aqueous humor (ARTRU, 1991) Thus, the relaxing effect of benzodiazepine might have influenced the changes in IOP observed in the present study.

In cats, rabbits, and monkeys, the ocular instillation of $1 \mathrm{mg}$ of xylazine decreased the IOP by decreasing the activity of the sympathetic innervations and the flow of aqueous humor (BURKE; POTTER, 1986). Trim, Colbern and Martin (1985) found that xylazine $(1.1 \mathrm{mg} / \mathrm{kg})$ IV attenuated the increase in IOP induced by of ketamine $(2.2 \mathrm{mg} / \mathrm{kg})$. The ocular structures in horses are different from those in rabbits, since the orbit is much larger compared with the globe, thus relaxation of the extraocular muscles from xylazine will have a greater impact on IOP in the horse. Despite this anatomical difference between the two species, this muscle relaxation effect of xylazine also might have occurred in the rabbits used in this study. It is also likely that the sympatholytic effects when xylazine administered topically; thus, one could speculate that xylazine administered IM could also have sympatholytic effects on IOP and could have contributed to the ketamine effects on IOP observed in this study.

To our knowledge, this is the first study investigating the effects of tiletamine-zolazepam on IOP. Zolazepam is commercialized in combination with tiletamine in equal proportions that has a myorelaxant effect that is two-fold more potent than diazepam (CALDERWOOD et al., 1971). Since zolazepam is a potent muscle relaxant, it is possible that it might have contributed to the decrease in IOP observed in this study; however, this cannot be stated given that the effects of drugs given alone were out of the scope of this study. Thus, more research would be necessary to elucidate the comparative effects of dissociative alone or in combination with benzodiazepines or $\alpha 2$-agonists in IOP in rabbits.

\section{Conclusions}

In conclusion, the three anesthetic combinations assessed in the current study decrease IOP in rabbits for up to 30 minutes when administered IM.

\section{References}

ARTRU, A. A. Intraocular pressure in anaesthetized dogs given flumazenil with and without prior administration of midazolam. Canadian Journal of Anaesthesia, Toronto, v. 38, n. 3, p. 408-414, 1991.

AUSINSCH, B.; RAYBURN, R. L.; MUNSON, E. S.; LEVY, N. S. Ketamine and intraocular pressure in children. Anesthesia and Analgesia, Riverwoods, v. 55, n. 6 , p. $773-775,1976$.

BRUNSON, D. B. Anesthesia in ophthalmic surgery. 
Veterinary Clinics of North America Small Animal Practice, Philadelphia, v. 10, n. 1, p.481-495, 1980.

BURKE, J. A.; POTTER, D. E. The ocular effects of xylazine in rabbits, cats, and monkeys. Journal Ocular Pharmacology, New Rochelle, v. 2, n. 1, p. 9-21, 1986.

CALDERWOOD, H. W.; KLIDE, A. M.; COHN, B. B.; SOMA, L. R. Cardiorespiratory effects of tiletamine in cats. American Journal Veterinary Research, Schaumburg, v. 32, n. 10, p. 1511-1515, 1971.

CUNNINGHAM, A. J.; BARRY, P. Intraocular pressure-physiology and implications for anesthetic management. Canadian Anaesthetic Society, Toronto, v. 33, n. 2, p. 195-208, 1986.

DUPRAS, J.; VACHON, P.; CUVELLIEZ, S.; BLAIS, D. Anesthesie du lapin de Nouvelle-Zelande utilisant les combinaisons tiletamine-zolazepam et ketaminemidazolam avec ou sans xylazine. Canadian Veterinary Journal, Ottawa, v. 42, n. 6, p. 455-460, 2001.

FLACKNELL, P. A.; RICHARDSON, C. A.; POPOVIC, A. Laboratory animals. In: TRANQUILLI, W. J.; THURMON, J. C.; GRIMM, K. A. (Ed.). Lumb \& jones'veterinary anesthesia and analgesia. $4^{\text {th }}$ ed. Blackwell Publishing: Ames, 2007. p. 765-784.

GHAFFARI, M. S.; MOGHADDASSI, A. P. Effects of ketamine-diazepam and ketamine-acepromazine combinations on intraocular pressure in rabbits. Veterinary Anaesthesia and Analgesia, Malden, v. 37, n. 3, p. 269-272, 2010.

GHAFFARI, M. S.; REZAEI, M. A.; MIRANI, A. H.; KHORAMI, M. The effects of ketamine-midazolam anesthesia on intraocular pressure in clinically normal dogs. Veterinary Ophthalmology, Malden, v. 13, n. 2, p. 91-93, 2010.

HOFMEISTER, E. H.; MOSUNIC, C. B.; TORRES, B. T.; RALPH, A. G.; MOORE, P. A.; READ, M. R. Effects of ketamine, diazepam, and their combination on intraocular pressures in clinically normal dogs. American Journal Veterinary Research, Schaumburg, v. 67, n. 7, p. 1136-1139, 2006.

TRIM, C. M.; COLBERN, G. T.; MARTIN, C. L. Effect of xylazine and ketamine on intraocular pressure in horses. Veterinary Record, London, v. 117, n. 17, p. 442443,1985 . 
